\title{
Personal Piety in Nordic Heathenism
}

\author{
By Åke V. STröm
}

Usually, Nordic heathenism is thought of as a fairy-tale or as an impersonal, collective event. Sacrifice (blót) and ethics appear to be the main facts. Was there anything at all like piety, and could it, in this case, be spoken of as personal? Lucien Musset says in his important work La conversione al christianesimo: "La paganisme nordique n'est guère une foi personelle" (Musset 1967, 265, "Nordic heathenism was never a personal faith"), and Walter Baetke decides without further notice: "Nicht um den einzelnen, seine Seele oder sein Schicksal handelt [es sich], sondern um die Gemeinschaft" (Baetke 1942,218 , "Not about the individual or his soul or destiny was the question, but about the community").

There is of course a good deal of truth in this. If we compare the northener with the modern westerner or with the Platonic Athenian, the inhabitant of the North stands out as a more collectively thinking person, attached to dynasty, housecarls and family. But the statements of Musset and Baetke are nevertheless exaggerations, and we would like to point out here a couple of examples in the texts of a "personal faith" and an interest in "the individual or his soul or destiny". We divide our material into two groups: personal opinion and personal means of expression.

\section{Personal opinion}

In old Icelandic there are two expressions including the word trua, 'believe': trúa einum, 'believe someone', and trúa á einum, '(personally) believe in someone or something'. Helge Ljungberg has, in a special study, maintained, that the last mentioned construction is only used in the Christian period (Ljungberg 1947, 153-165), and this is applauded by Baetke's pupil, Ernst Walter (Walter 1966, 367, note 36). But Geo Widengren has suggested that the age of the texts with trúa á points towards the pagan period (Widengren 1966, 330) and A.G. van Hamel has already shown that one can use the same expression for belief in gods and in men (Hamel 1936, 27). We have such phrases as: "I was confident in believing him [Odin]" (Gerðumk tryggr at trúa honum, 
Egill Skallagrímsson, Sonatorek, st. 22) or "Then I should believe in you [Thor]" (Ek mynda pér pá trúa, Harbarsljóð, st. 34). Here we really have "une foi personelle" in pagan time.

The examples of personal change of faith point in the same direction. Sigurður Nordal has shown that Egill Skallagrímsson was converted from belief in Thor to belief in Odin (Nordal 1924, 145-165). The best example is perhaps Glumr á pverá. He belonged to a family, whose ancestors worshipped Thor, while the other family members kept to Frey. They had a Frey-sanctuary of their own and organized stallion baitings in his honour, but we read that, after a remarkable dream, Glum "got angry with Frey" (létsk verr vera við Frey, Gluma, ch. 26), and Anne Holtsmark concludes from different criteria, that Glum assumed the faith in Odin of his maternal family. Hallfreðr Vandrædaskald confesses, even as a Christian, that he has had a personal relationship with Odin and with his fylgia, but that when he has had an accident on board ship, he says to the fylgia: "I cease totally to be friends with you" ( $i$ sundr segi ek gllu við pik, Hallfr. saga, ch. 11).

The personal feature in the Nordic religion appears thirdly from the surprising fact that there are a number of impious and atheistic people in the texts: Arnljótr Gellini, Hrolfr Kraki, Sigmundr Brestisson and above all Gaukaporir and Afrafasti, who declare: "We believe in ourselves and in our strength" (trúm á okkr ok afl okkat, S:t Olavs saga, ch. 201). ${ }^{1}$

The case is somewhat similar in the ethical sphere. The word for conscience, Gothic mipwissi, Nordic samwizka and samvitand, is a translation of conscientia and is not used until Christian times (de Vries 1956, 175). It means a sentiment of correspondence to, or a deviation from, a common ethical ideal. But in pagan times we have a counterpart in the totally private field: the feeling of violation of one's own honour.

Egill Skallagrímsson and his men had been captured by a peasant in Kurland. The latter wanted to slay the prisoners at once, but his son asked him to postpone the execution until the next morning in order to let everyone have a better look at them being killed. The captives were locked up over night in the storehouse, but they succeeded in escaping from here with supplies and arms.

Out in the forest a consideration awoke in Egill, some sort of cor-

1 Tor Andræ first pointed to this fact (Andræ 1932, $31 \mathrm{ff}$.). Ljungberg and Folke Ström have dealt with it further. Ljungberg 1940, 147-155; Ström F. 1948, 16-28. 
respondence to our sense of conscience, and he said: "This was very bad. We have stolen the property of our host, the peasant, without his knowing. Such a shame must not overcome us". And he returned alone - not to give back the stolen things but to set the whole farm on fire and to burn everyone to death! Egil's men are said to have been very happy when he returned and told them what he had done (Saga Egils Skallagrímsonar, ch. 46). He had saved "their soul and their destiny".

\section{Personal means of expression}

Norsemen expressed their personal relationship to the gods by sacrifice. Floki Vilgerðarson offered (blótað̌i) for a good voyage (Lndb. St. ch. 5). One could sacrifice personally for victory, health, long life, etc. (Ström, A. V. 1975, 220 ff.).

Prayer serves the same purpose. But as a matter of fact prayer, which is said to be the breath of religious belief, is seldom mentioned in Nordic texts. In the "priest-mirror" (Háv. st. 144) we read:

Veitstu, hvé bidja skal?

Veitstu, hvé blóta skal?
Understandeth thou to pray?

Understandeth thou to sacrifice?

but there prayer (and sacrifice) are mentioned as sacerdotal functions (Ström, $\AA$. V. 1975, 275). There are in fact some examples of a personal connection between a single person and his god, for instance when Hrólfr in the Eyrbyggjasaga is called "Thor's good friend" ( mikill vinr pórs, ch. 3), even his "love-friend" (ástvinr, ch. 4). Hrafnkell had Frey as his friend, "dearer than other gods" (elskadi eigi annat god meir, Hrafnk, ch. 2).

One single prayer is handed down to us in the texts, which is the one of Thorkell the High on Thverá, beginning like this:

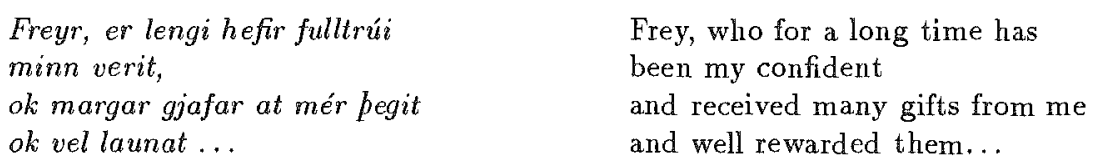

(Glúma, ch. 9, Ljungberg 1940, 124 note 1). Of women's prayers we have some traces in Oddr. st. 9 , where it is said that it was customary to call on Frigg and Freya in childbed.

This was the sum occurence of personal prayers in the Nordic texts until some years ago. In 1987, there appeared a learned treatise by 
the late Swedish runologist, Ivar Lindquist, concerning the very little known amulet from Kvinneby on the island of Öland. The pertinent part of the difficult text was decoded and translated by Lindquist as follows:

1. Ek hæR - I yrki vĩss em - undiRgub, bì eR berg'k Bōfi maeR. Fuld, Thūp es pæR viss.
I praise the goddess underneath - I am wise in poetry as I, Bofi, have my livelihood.

Oh Earth, you have the consideration of a skilful one.

Alternative reading:

1. Ek hæRR $\mathbb{E r k u}^{2}$ - viss em ...

2. Ėnburr (h) aldi illu frān Bōra!

Pōrr gaêti hans meR pēm hamri, es $\bar{A} m$ hyRR, haf i gā $\bar{A} m$ ?

3. Fly̆, frän illvêtt! Faer ekki af $B \bar{o}$.

Gup eRu undir hānum auk yfiR hānum.

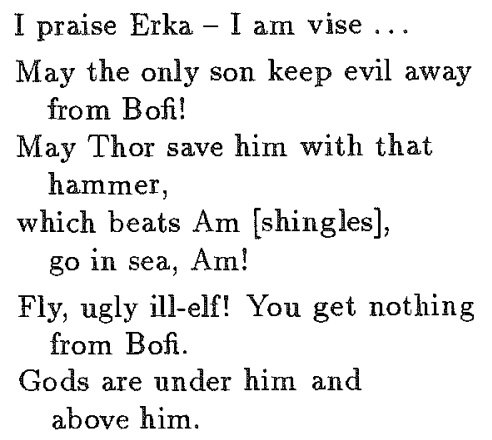

Regarding this inscription, Lindquist wrote as follows: "This religious text is personal, because it allows the writer in many places to appear in his own name and call attention to himself as an object of the mercy of the gods. Bofi, as he is called, is formulating himself in verse. He is humble in approaching the powers - a genuine religious feature. The literary style which Bofi uses must once have been the pious way of speaking to the powers used by our Nordic heathen ancestors" (Lindquist 1987, $78 \mathrm{f}$.). This very text "puts the Thor religion in a new surprising light, by giving us a portrait of one of its practicants, recorded during a cult ceremony, the prayer. The evidence is in its way unique" (Lindquist 1987, 80).

Another personal document seems to be found in the text of the Safety-pin from Nordendorf (Die Bügelfibel Nordendorf I). A recent interpretation and translation is made by the Norwegian scholar Ottar Grønvik (Grønvik 1985, 111-129):

2 Cf. The Anglo-Saxon ground-blessing line 49: Erce, Erce, Erce eoðan modor, "Erke, Erke, Erke, mother of the ground!" 
logapore wodan wigibonar awa leubwiniç

Liars are Odin and Dedicating-Thor. Ava and Leubvini.

Grønvik says about this: "Möglicherweise handelt es sich um eine eheliche Verbindung zwischen einem Heiden und einer Christin, bei der die Forderung gestellt wurde, daß Leubvini zuvor seinem heidnischen Glauben abschwören sollte" (Grønvik 1985, 126). Consequently we have here a personal matrimonial document as well as a personal renuntiation formula.

Cf. a similar but female incantation on the Sigtuna-amulet (Lindquist $1932,73)$.

Another personal means of expression is the outdoor sitting (útiseta). It is said of the seeress in the Edda:

Ein sat hon úti

pá er hin aldni kom.

(Vsp. st. 28)
She was sitting alone outdoors, when the Old man came.

The Norwegian expert Gro Steinsland declares outdoor sitting to be "a technical term for foreboding" (Steinsland 1979, 139). Later on, in a personal letter to me (23.3.1987), she provided further evidence of this by quoting the Law of Gulathing $\S 32$ and the Law of Frostathing $\S \S 5$ and 45 . Dag Strömbäck has already dealt with this expression. He is inclined, as he says, to see in this "the habit of the wise and farseeing man to sit outdoors in order to gain spatial information about hidden things" (Strömbäck 1935 128, not 5). This útiseta, Strömbäck adds, "was always carried on without assistants", contrary to the sejd, the Nordic divination (Strömbäck 1935, 127). Consequently, it is an expression of a purely personal piety.

Present-day Odin religion speaks frequently of sitting out-doors, and apparently that is put into practice. We find "Instructions for sitting out-doors" in the journal of the Yggdrasil society (Eriksson $1982,3 \mathrm{f}$.), and a general article on the same subject in an other copy (Eriksson 1983, 13-15), being reprinted two years later (Eriksson 1985, $30 \mathrm{ff}$.). The article ends: "And when the trees begin to dance, let them continue" (Eriksson 1983, 15; Eriksson 1985, 32).

We return to antiquity. The oath has a close connection with religion. If one did not believe, or no longer believed, in the gods, the oath had no power. But he who broke an oath brought down the rage of the gods. In spite of there being several witnesses to the oath (Early Westgothic Law, Marriage Code, $\S 9$ ), the taking of an oath was the 
task of one single person. It had reference to the individual and his destiny.

It is quite clear, that the collective and impersonal traits in old Norse religion were far more prominent than in the religious currents of today (cf. Ström, $\AA$.V. 1944, 29-45, 71-76). But there was in Nordic paganism a personal piety, too. It appeared not only in personal opinion and personal means of expression, but also in daily life as well. The single peasant, Viking, fisherman, artisan, hou sewife, was in his or her everyday work totally dependent on the blessing of the gods and on protection from the attacks of the demons (de Vries 1936, 208). He who succeeded enjoyed this personal success because of personal sacrifices, personal fortune and personal blessing.

\section{Bibliography}

Andræ, Tor 1932. Die Frage der religiösen Anlage. Uppsala universitets årsskrift 1932, Program 5. Uppsala.

Baetke, Walter 1942. Das Heilige im Germanischen. Tübingen.

Eriksson, J. I. 1982. Instruktioner för ute-sittning. Gimle 5. Stockholm.

- 1983. Instruktioner för ute-sittning. Gimle 7. Stockholm.

- 1985. Ute-sittning. Sejd. Stockholm.

Grønvik, Ottar 1985. Die Runeninschrift der Nordendorfer Bügelfibel 1. Runor och runinskrifter. (Kungl. Vitterhets Historie och Antikvitets Akademien. Konferenser 15.) Stockholm.

Hamel, A. G. van 1936. Islands Odinsgeloof. Amsterdam.

Holtsmark, Anne 1933. Vitazgjafti. Maal og Minne. Oslo.

Lindquist, Ivar 1932. Religiösa runtexter 1 . Lund.

- 1987. Religiös a runtexter 3 . Lund.

Ljungberg, Helge 1940. Den nordiska religionen och kristendomen. (Nordiska texter och undrsökningar utg. i Uppsala av Bengt Hesselman 11.) Uppsala.

- 1947. Trúa. Arkiv för nordisk filologi 62. Lund.

Musset, Lucien 1967 La pénétration chrétienne dans l'Europe du Nord. La conversione al cristianesimo nell'Europa dell' alto medioevo. (Settimane di studio del Centro italiano di studi sull'alto medioevo 14.) Spoleto.

Nordal, Sigurður 1924. Atrúnadur Egils Skallagrimsonar. Skírnir 98. Reykjavik.

Steinsland, Gro 1979. Treet i Völuspá. Arkiv för nordisk flologi 94. Lund.

Ström, Folke 1948. Den egna kraftens män. Göteborgs högskolas årsskrift 54, 2. Göteborg.

Ström, Åke V. 1944. Vetekornet. Uppsala. 
Ström, Åke V. 1975. Germanische Religion. Germanische und Baltische Religion. Von A. V. Ström \& H. Biezais. (Religionen der Menschheit 19,2.) Stuttgart.

Strömbäck, Dag 1935. Sejd. (Nordiska texter och undersökningar utg. i Uppsala av Bengt Hesselman 5.) Uppsala.

Vries, Jan de 1956. Altgermanische Religionsgeschichte 1. (Grundriss der germanischen Philologie 12,1.) Berlin.

Walter, Ernst 1966. Quellenkritisches und Wortgeschichtliches zum Opferfest von Hladir in Snorris Heimskringa (Hák. gód. c. 17). Festschrift Walter Baetke. Weimar.

Widengren, Geo 1966. Archivio di Filosofia. Roma. 